\title{
UJI KADAR DISOLUSI TABLET KALSIUM LAKTAT MENGGUNAKAN TITRASI KOMPLEKSOMETRI
}

\author{
Reni Aisyah Simbolon, Ulil Amna, Halimatussakdiah \\ ${ }^{1}$ Program Studi Kimia Fakultas Teknik Universitas Samudra \\ Jl. Meurandeh, Langsa Aceh 24416, Indonesia \\ ${ }^{*}$ Corresponding author: reniaisyahh18@gmail.com
}

\begin{abstract}
ABSTRAK
Pengujian disolusi tablet Kalsium Laktat betujuan untuk memastikan kadar zat aktif dari kalsium laktat dapat terlarut dalam tubuh sehingga mencapai efek terapi yang diinginkan. Alat yang digunakan adalah Disolusion Tester merk Hanson type Vision G2 Elite $8^{\mathrm{TM}}$ dengan menggunakan metode keranjang. Media yang digunakan adalah aquadem dengan volume $500 \mathrm{ml}$ tiap vesselsnya (tabung disolusi). Pengukuran kadar tablet kalsium laktat diukur menggunakan titrasi kompleksometri, dimana indikator yang digunakan adalah indikator EBT dan larutan standar yang digunakan adalah EDTA. Dari hasil pengujian didapatkan kadar ratarata tablet kalsium laktat sebesar $101,61 \%$ dengan kadar minimun $98,46 \%$. Hasil ini menunjukkan bahwa tablet Kalsium Laktat yang di produksi oleh PT. Kimia Farma (Persero) Tbk. Plant Medan memenuhi syarat sesuai dengan yang tertera di Farmakope Indonesia Edisi $\bigvee$ yaitu tiap unit sediaan tidak kurang dari $Q+5 \%$ $=80 \%$, dimana $\mathrm{Q}=75 \%$.
\end{abstract}

Kata Kunci: Kalsium Laktat, Disolusi, Disolusi Tipe Keranjang, Titrasi Kompleksometri

\section{PENDAHULUAN}

Kalsium merupakan mineral yang paling banyak terdapat didalam tubuh, yaitu sebanyak $2 \%$. Salah satu dokter ahli gizi mengemukakan bahwa kebutuhan kalsium orang indonesia ratarata 500-800 $\mathrm{mg} / \mathrm{hari}$. Pada usia lanjut dan wanita menopause, asupan kalsium yang dibutuhkan meningkat menjadi $1.000 \mathrm{mg} / \mathrm{hari}$. Bila kadar kalsium darah turun di bawah normal makatubuh akan mengambil kalsium dari tulang agar kalsium dalam darah dapat seimbang. Pengambilan kalsium dari tulang secara terusmenerus dapat menyebabkan pengeroposan tulang. Oleh karena itu penting untuk menjaga keseimbangan kalsium [3]. Pada usus halus, absorpsi kalsium merupakan satu-satunya sumber kalsium bagi pembentukan tulang sehingga berpengaruh tehadap densitas dan kekuatan tulang yang secara langsung mempengaruhi aktivitas fisik [2].

Kalsium laktat adalah suatu garam kalsium yang berfungsi menjamin kebutuhan kalsium dalam tubuh [3]. Kalsium laktat dapat meningkatkan kemampuan pengikatan air dan juga dapat berfungsi sebagai pembentuk tekstur, penstabil serta pengental [1]. Kalsium Laktat juga banyak digunakan sebagai fortifikasi kalsium sebagai tingkat absorpsi tinggi di industri pangan dan obat-obatan. Kalsium laktat diakui aman dan dapat digunakan sebagai agen penguat, penambah rasa, pengasam, suplemen, agen anti bakteri, sebagai bahan pembuatan biomaterial substitusi tulang serta sebagai agen antitartar pada pasta gigi [4]. Kalsium laktat dapat diproduksi salah satunya dalam bentuk tablet.

Tablet merupakan sediaan padat yang dibuat secara kempa-cetak, berbentuk rata atau cembung rangkap yang umumnya bulat dan mengandung satu jenis obat atau lebih dengan atau tanpa adanya zat tambahan. Zat tambahan yang digunakan dapat berfungsi sebagai zat pengisi, zat pengembang, zat pengikat, zat pelicin dan zat pembersih [1]. Tablet harus melepaskan zat berkhasiat kedalam tubuh dalam jumlah yang sesuai sehingga menimbulkan efaek yang diinginkan jika memiliki mutu dan kadar yang sesuai. Untuk menghasilkan mutu dan kadar yang baik dan memenuhi persyaratan, pemilihan dan kombinasi bahan pembantu memiliki peranan penting dalam proses pembuatan tablet.

\section{BAHAN DAN METODE}

\section{Bahan}

Bahan yang digunakan adalah 6 tablet kalsium laktat, aquadem, larutan buffer ammonia, indikator Erichrome Black $T$ (EBT) dan larutan baku Etilendiaminetetraacetic Acid (EDTA) 0,05 M. 


\section{Metode}

\section{Penimbangan Sampel}

Sampel tablet kalsium laktat ditimbang menggunakan timbangan semimikro merk balance metler toledo dengan range 570-630 mg per tabletnya.

2. Pembuatan Buffer Ammonia

Ditimbang $\mathrm{NH}_{4} \mathrm{Cl}$ sebanyak 17,6 gram, kemudian ditambahkan $\mathrm{NH}_{4} \mathrm{OH}$ sebanyak $142 \mathrm{~mL}$, lalu ditambahkan akuades hingga $250 \mathrm{~mL}$

3. Pembuatan Indikator Erichrome Black T (EBT)

Ditimbang serbuk EBT sebanyak $200 \mathrm{mg}$, kemudian ditambahkan Trietanolamin sebanyak $15 \mathrm{~mL}$ dan ditambahkan metanol sebanyak $5 \mathrm{~mL}$. diaduk hingga homogen.

\section{Pembuatan Larutan}

\section{Etilendiaminetetraacetic Acid (EDTA)} $0,05 \mathrm{M}$

Ditimbang EDTA sebanyak 20,82 gr, kemudian ditambahkan akuades hingga 100 $\mathrm{mL}$.

\section{Uji Disolusi}

Dihidupkan alat disolusi tester, kemudian disiapkan 6 vessels (tabung gelas disolusi). Diatur suhu pada tabung hingga $37^{\circ} \mathrm{C} \pm 0,5^{\circ} \mathrm{C}$ dengan kecepatan 100 rpm dengan waktu 45 menit. Dimasukkan media aquadem sebanyak $500 \mathrm{~mL}$ pada masing-masing vessels lalu ditunggu hingga suhu stabil $37^{\circ} \mathrm{C} \pm 0,5^{\circ} \mathrm{C}$. Dipasang metode keranjang, lalu dimasukkan tablet kalsium laktat pada masing-masing keranjang, kemudian dilakukan uji disolusi selama 45 menit.

\section{Penetapan Kadar dengan Titrasi dalam Uji Disolusi}

Setelah 45 menit alat dijalankan, dimatikan alat. Diambil cuplikan dengan spuit sebanyak $50 \mathrm{~mL}$ dari masing-masing Vessels lalu dimasukkan kedalam erlenmeyer $250 \mathrm{~mL}$. Kemudian ditambahkan $5 \mathrm{~mL}$ larutan buffer ammonia dan 1 tetes indikator EBT. Dititrasi larutan tersebut menggunakan larutan baku EDTA $0,05 \mathrm{M}$ sampai terjadi perubahan warna dari merah rose menjadi biru lembayung.

\section{HASIL DAN PEMBAHASAN}

\section{Data Hasil Disolusi}

Data hasil penelitian Uji Disolusi Tablet Kalsium Laktat Dengan Metode Keranjang dapat dilihat pada tabel 1 berikut ini: Tabel 1 Hasil Uji Disolusi

\begin{tabular}{ccccc}
\hline No & Sampel & $\begin{array}{c}\text { Bobot } \\
\text { Sampel }\end{array}$ & $\begin{array}{c}\text { Volume } \\
\text { Titrasi }\end{array}$ & Kadar \\
\hline & 1 & 601,2 & 3,1 & $102,72 \%$ \\
$\vdots$ & 2 & 597,0 & 3,0 & $98,70 \%$ \\
$\vdots$ & 3 & 599,6 & 3,1 & $102,43 \%$ \\
$<$ & 4 & 607,6 & 3,2 & $107,15 \%$ \\
$\vdots$ & 5 & 606,1 & 3,0 & $100,22 \%$ \\
6 & 6 & 595,5 & 3,0 & $98,46 \%$ \\
\hline \multicolumn{5}{c}{ Rata-rata } \\
\hline
\end{tabular}

Prinsip dasar alat disolusi yang digunakan ialah kadar zat aktif yang terlarut dalam tubuh berdasarkan media dan kecepatan perputarannya. Alat yang digunakan untuk uji disolusi ini yaitu dissolution tester merek Hanson type Vision G2 Elite $8^{\mathrm{TM}}$, dengan menggunakan metode keranjang. Media yang digunakan adalah aquadem sebanyak $500 \mathrm{~mL}$ per vessels dengan suhu $37^{\circ} \mathrm{C} \pm 0,5^{\circ} \mathrm{C}$ disesuaikan dengan suhu tubuh manusia. Media aquadem digunakan untuk menyesuaikan keadaan fisiologis di dalam lambung dengan kecepatan perputaran 100 rpm yang menggambarkan gerakan peristaltik lambung. Hal ini disesuaikan dengan tubuh manusia karena pengujian disolusi ini untuk mengetahui pelarutan obat dalam cairan tubuh. Setelah 45 menit di ambil cuplikan dalam masing-masing vessels sebanayak $60 \mathrm{~mL}$ menggunakan spuit yang sudah terpasang membran filter. Penggunaan membran filter bertujuan untuk menyaring zat pengotor yang mungkin terdapat dalam cuplikan. Setelahnya, cuplikan di ukur sebanyak $50 \mathrm{~mL}$ dan dimasukkan kedalam erlenmeyer $250 \mathrm{~mL}$.

2. Hasil Penetapan Kadar Titrasi dalam Uji Disolusi

Pada titrasi kompleksometri yang dilakukan, diperoleh volume larutan standar EDTA yang habis terpakai dari masing-masing cuplikan. Dengan demikian dari hasil volume EDTA yang habis terpakai dapat dihitung kadar dari masingmasing cuplikan. Dari hasil perhitungan yang diperoleh persen kadar disolusi cuplikan yaitu 
kadar disolusi vessels 1 adalah 102,72\%, vessels 2 adalah 98,70\%, vessels 3 adalah $102,43 \%$, vessels 4 adalah $107,15 \%$, vessels 5 adalah 100,22\% dan vessels 6 adalah 98,46\%. Hasil tersebut memenuhi syarat sesuai dengan yang tertera di Farmakope Indonesia Edisi V yaitu tiap unit sediaan kalsium laktat tidak kurang dari $Q+5 \%=80 \%$, dimana $Q=75 \%$. Dan dapat melarut dengan baik sesuai dengan ketentuan.

Reaksi pembentukan ion kompleks yang terjadi adalah:

- $\mathrm{Ca}^{2+}+2 \mathrm{NH}_{3}+2 \mathrm{H}_{2} \mathrm{O} \rightarrow \mathrm{Ca}(\mathrm{OH})_{2}+$ $2 \mathrm{NH}^{4+}$

- $\mathrm{Ca}(\mathrm{OH})_{2}+4 \mathrm{NH}_{3} \rightarrow\left[\mathrm{Ca}\left(\mathrm{NH}_{3}\right)_{4}\right]^{2+}+2 \mathrm{OH}^{-}$

- $\mathrm{Ca}^{2+}+\mathrm{EBT} \rightarrow \mathrm{CaEBT}$

- $\mathrm{CaEBT}+\mathrm{EDTA} \rightarrow \mathrm{CaEDTA}+\mathrm{EBT}$

\section{KESIMPULAN}

Berdasarkan hasil pengujian kadar disolusi tablet kalsium laktat yang di produksi di PT. Kimia Farma (Persero) Tbk. Plant Medan memenuhi syarat sesuai dengan yang tertera di Farmakope Indonesia Edisi $\mathrm{V}$ yaitu tiap unit sediaan tidak kurang dari $Q+5 \%=80 \%$, dimana $Q=75 \%$. Kadar rata-rata tablet kalsium laktat yang diperoleh adalah $101,61 \%$ dan kadar minimun $98,46 \%$.

\section{UCAPAN TERIMA KASIH}

Kami mengucapkan terimakasih kepada semua pihak yang telah membantu dalam menjalankan penelitian ini.

\section{REFERENSI}

[1] Catherina, C. I., Sutarjo, S., dan Erni, S. "Pengaruh Konsentrasi Perendaman Kalsium Laktat terhadap Sifat Fisikokimia Mashed Sweet Potato Powder", Jurnal Teknologi Pangan dan Gizi 15 (2), 65-71 (2016)

[2] Muliani, I., Nyoman, M. K., dan Ketut, T. "Pemberian Kalsium Laktat dan Berenang Meningkatkan Osteoblast pada Epiphysis Tulang Radius Mencit Perimenopause", Jurnal Veteriner 15 (1), 39-45 (2014)

[3] Ningsih, W., Firmansyah, Nova, J. "Formulasi Tablet Kunyah Kalsium Laktat dengan Variasi Konsentrasi sebagai Bahan Pengikat terhadap Sifat Fisiknya", JIFFK 14 (1), 30-35 (2017)

[4] Prayitno, A. H., Edi, S., dan Rusman. "Pengaruh Fortifikasi Nanopartikel Kalsium Laktat Kerang Telur terhadap Sifat Kimia dan Fisik Bakso Ayam", Buletin Peternakan 40 (1) ,40-47 (2016)

[5] Anief, M, "Ilmu Meracik Obat", Penerbit Gadjah Mada University Press, Yogyakarta, 2000 